TARNOWSKIE STUDIA TEOLOGICZNE 34 (2015) nr 1, s. 182-184

http://dx.doi.org/10.15633/tst.1579

ks. Paweł Lewandowski

KATOLICKI UNIWERSYTET LUBELSKI JANA PAWEA II

\title{
ks. K. Mikołajczuk, Uprawnienia Kardynata Stefana Wyszyńskiego wobec Kościoła Greckokatolickiego w archiwaliach Prymasa i Konferencji Episkopatu Polski, Wydawnictwo Archidiecezji Lubelskiej „Gaudium”, Lublin 2014, ss. 599
}

Sługa Boży kard. Stefan Wyszyński (1901-1981), arcybiskup metropolita warszawsko-gnieźnieński, prymas Polski i przewodniczący Konferencji Episkopatu Polski pełnił z oddaniem te funkcje w napiętej sytuacji społeczno-politycznej w naszym kraju. W trudnych warunkach zagrożenia ze strony reżimu komunistycznego podejmował starania mające na celu łagodzenie konfliktów na linii rząd - opozycja. Pełnił także rolę pośrednika między władzą a „Solidarnością”. Całą swoją pasterską posługę skupił na działaniach mających na celu przeprowadzenie polskiego Kościoła przez niesprzyjające dla jego funkcjonowania lata komunizmu. Najlepszym świadectwem szacunku, na jaki zasługuje kard. Stefan Wyszyński, są słowa św. Jana Pawła II wypowiedziane w dniu inauguracji pontyfikatu: „Nie byłoby na Stolicy Piotrowej tego papieża Polaka, który dziś pełen bojaźni Bożej, ale i pełen ufności rozpoczyna nowy pontyfikat, gdyby nie było Twojej wiary, nie cofającej się przed więzieniem i cierpieniem, Twojej heroicznej nadziei, Twego zawierzenia bez reszty Matce Kościoła, gdyby nie było Jasnej Góry i tego całego okresu dziejów Kościoła w Ojczyźnie naszej, które związane są z Twoim biskupim i prymasowskim posługiwaniem".

Przedmiotem publikacji ks. dr. hab. Krzysztofa Mikołajczuka, adiunkta w Katedrze Prawa Katolickich Kościołów Wschodnich Katolickiego Uniwersytetu Lubelskiego Jana Pawła II, jest analiza specjalnych uprawnień wobec Kościoła Greckokatolickiego, jakie na czas trudnej historii Kościoła w powojennej Polsce kard. Stefan Wyszyński otrzymał od Stolicy Apostolskiej.

Powodem, dla którego prezentowana monografia jest szczególnie wartościowa, jest fakt, iż na jej materiał źródłowy składają się przede wszystkim niepublikowane dotąd dokumenty zgromadzone w archiwaliach Prymasa Polski i Konferencji Episkopatu Polski; z zasady trudno dostępne, niektóre rozproszone, jak do tej 
pory nieopracowane i nieskatalogowane. Wśród nich można wyróżnić dokumenty różnych dykasterii Kurii Rzymskiej, pisma kard. Stefana Wyszyńskiego, a także biskupów, proboszczów, administratorów parafii, przełożonych instytutów życia konsekrowanego i stowarzyszeń życia apostolskiego, prezbiterów rzymsko- i greckokatolickich, a także wiernych obu obrządków. Ze strony rządowej materiał źródłowy stanowią dokumenty Komitetu Polskiej Zjednoczeniowej Partii Robotniczej oraz niższych rangą urzędników państwowych tak instytucji centralnych, jak i lokalnych.

Monografia Uprawnienia Kardynała Stefana Wyszyńskiego wobec Kościoła Greckokatolickiego w archiwaliach Prymasa i Konferencji Episkopatu Polski składa się z trzech rozdziałów i obszernego aneksu źródłowego.

Rozdział pierwszy zatytułowany Zarys kościelnych relacji łacińsko-wschodnich na ziemiach polskich (s. 25-128) uznać można za wprowadzenie w podejmowaną rozprawę, bez którego trudno byłoby zrozumieć specyficzne kościelne relacje łacińsko-wschodnie na ziemiach polskich. W rozdziale tym ks. dr hab. Krzysztof Mikołajczuk skupia się na pięciu zagadnieniach: Unia Brzeska (troska o jedność, ogniska prounijne, działania na rzecz unii, kontekst i warunki unii z Kościołem katolickim, postanowienia zjazdu w Torczynie, Synod Brzeski i jego postulaty, podpisanie unii, przyjęcie i proklamacja unii kościelnej oraz trwałość Unii Brzeskiej); działalność i reformy Kościoła unickiego (problem zmiany obrządku, „Artykuły” abp. Jana Skarbka, Synod Zamojski, Bractwa cerkiewne oraz społeczność unicka w miastach); Kościół unicki w okresie zaborów (zabór rosyjski, Królestwo Kongresowe, Galicja oraz próby przywrócenia Kościoła greckokatolickiego); Kościół greckokatolicki w Polsce w pierwszej połowie XX wieku (I wojna światowa, okres międzywojenny oraz II wojna światowa); a także Kościół greckokatolicki w Polsce po II wojnie światowej (likwidacja Kościoła greckokatolickiego, akcja „Wisła”, grekokatolicy i ich działalność w podziemiu oraz odrodzenie Kościoła greckokatolickiego).

W rozdziale drugim Kardynat Stefan Wyszyński-podmiot uprawnień specjalnych (s. 129-238) Autor przedstawia człowieka niezłomnego, który stał na czele Kościoła katolickiego w Polsce czterdzieści trzy lata (1948-1981). Materiał tego rozdziału podzielony został na trzy grupy tematyczne: Stefan Wyszyński - rys biograficzny (dom rodzinny, nauka, czas wojny, biskup lubelski, nominacja na prymasa Polski, śmierć Prymasa); wybrane poglądy prymasa Stefana Wyszyńskiego (socjalizm i komunizm według Prymasa, nauczanie społeczne, obrońca historii, tradycji i kultury Polski oraz rola narodu); zarys działalności kard. Stefana Wyszyńskiego (porozumienie z komunistami, specjalne uprawnienia Prymasa, Non possumus, lata 1953-1956 - uwięzienie Prymasa, Śluby Jasnogórskie i Wielka Nowenna oraz Orędzie biskupów polskich do biskupów niemieckich).

Rozdział III zatytułowany Kardynat Stefan Wyszyński zwierzchnik Kościoła Greckokatolickiego w Polsce (s. 239-348) ukazuje Prymasa Polski jako zatroskanego pasterza, męża stanu i doskonałego stratega w grach politycznych. Ta część monografii ks. dr. hab. Krzysztofa Mikołajczuka przedstawia zakres i realizację specjalnych uprawnień kard. Stefana Wyszyńskiego otrzymanych od Stolicy 
Apostolskiej wobec duchowieństwa i wiernych Kościoła Greckokatolickiego. Rozdział ten budują dwa obszary zagadnień: zakres uprawnień Prymasa w dokumentach archiwalnych (zarys historii prymasostwa i uprawnień prymasów w Polsce, kontekst historyczny nadanych uprawnien, uprawnienia nadzwyczajne-facultates speciales); oraz realizacja uprawnień kard. Stefana Wyszyńskiego (polityka władz i Kościoła rzymskokatolickiego wobec ludności ukraińskiej w powojennej Polsce oraz realizacja uprawnień specjalnych - ilustracja dokumentów archiwalnych).

Obszerny aneks (s. 359-572) dopełniający całość analizowanego przez Autora zagadnienia zawiera wyłącznie niepublikowane dotąd materiały źródłowe: 111 dokumentów z Archiwum Prymasa Polski mieszczącym się przy ul. Miodowej w Warszawie oraz 23 dokumenty z Archiwum Konferencji Episkopatu Polski (wypada zaznaczyć, że odnajdujemy tutaj tarnowskie akcenty) - wszystkie w formie druku komputerowego, a także 6 fotokopii z Archiwum Prymasa Polski (m.in. pismo Sekretariatu Stanu do abp. Stefana Wyszyńskiego dotyczące uprawnień specjalnych, zaświadczenie Sekretariatu Stanu, że kard. Stefan Wyszyński posiada uprawnienia ordynariusza miejsca w odniesieniu do Kościoła Greckokatolickiego w Polsce wraz z thumaczeniem, czy deklarację Świętej Kongregacji dla Kościoła Wschodniego, że kard. Stefan Wyszyński jest ordynariuszem dla wiernych obrządków greckokatolickiego i ormiańskiego w Polsce).

Publikację wieńczy literatura przedmiotu (s. 573-599), która - jak zauważa Autor - ,pozwala czytelnikowi jeszcze łatwiej dotrzeć do interesujących go zagadnień, które może $\mathrm{w}$ niedostatecznym stopniu zostały poruszone $\mathrm{w}$ prezentowanej monografii" (s. 24).

Reasumując, przedmiotem analizy ks. dr. hab. Krzysztofa Mikołajczuka zawartej w monografii Uprawnienia Kardynała Stefana Wyszyńskiego wobec Kościoła Greckokatolickiego w archiwaliach Prymasa i Konferencji Episkopatu Polski, opublikowanej nakładem Wydawnictwa Archidiecezji Lubelskiej „Gaudium”, stały się specjalne uprawnienia nadane kard. Stefanowi Wyszyńskiemu przez Stolicę Apostolską - najpierw jako ordynariuszowi miejsca (władza delegowana), później jako biskupowi diecezjalnemu (władza zwyczajna). W swojej publikacji Autor obszernie przedstawił zakres i wyjątkowy sposób realizacji owych uprawnień w niezwykle specyficznym czasie, absolutnie niesprzyjającym Kościołowi. Z reżimu komunistycznego Kościół w Polsce wyszedł jednak zwycięsko, co - jak dowiódł ks. dr hab. Krzysztof Mikołajczuk - było niemałą zasługą kard. Stefana Wyszyńskiego. Bezdyskusyjną zaletą prezentowanej monografii jest bogata literatura źródłowa, jak dotąd nieopracowana. Wszystko to sprowadza się do stwierdzenia, że publikacja Uprawnienia Kardynała Stefana Wyszyńskiego wobec Kościoła Greckokatolickiego w archiwaliach Prymasa i Konferencji Episkopatu Polski stanowi wartościowe i godne polecenia źródło wiedzy nie tylko dla prawników czy historyków, ale także szerokiego gremium czytelników zainteresowanych osobą i dziełem wielkiego Prymasa Tysiąclecia. 